Shamieh, Luna, ${ }^{1}$ Molnár, Dóra ${ }^{2}$

\title{
The Impact of Counterinsurgency on Human Security. The case study of Iraq (2003-2011)
}

DOI 10.17047/Hadtud.2021.31.E.99

Iraq mosaic formed of the different minorities survived for a long while; a beauty that has not remained for long. The mosaic changed to ruins following the counterinsurgency. The war in Iraq led to a complete chaos against all aspects of the society. It has caused a massive influx of migration and displacement; it also led to fragmentation in the society that eventually culminated in deterioration in human security of all the people from different communities. The political, personal and community security issues and challenges are discussed in the study showing political repression, human rights violations, lack of rule of law and justice, physical violence, human trafficking, inter-ethnic tensions and terrorism.

KEYWORDS: insurgency, counterinsurgency, human security, political security, personal security, community security, Iraq

\section{Felkelés elleni müveletek hatása a humán biztonságra Esettanulmány Irak példája alapján (2003-2011)}

A különféle kisebbségekböl kialakitott iraki mozaik sokat látott és még többet túlélt, azonban mégsem maradhatott fenn. A felkelés leverése következtében a mozaik romokká vált. Az iraki háború a társadalom valamennyi szegmensében teljes káoszhoz vezetett, valamint hatalmas migrációs és kitelepitési hullámot idézett elö. A társadalom széttagoltságához vezetett, amely elkerülhetetlen következménye lett a különbözö közösségekböl származók humán biztonságának jelentös romlása. A tanulmány a politikai, egyéni és közösségi biztonsági kérdéseket és kihívásokat tárgyalja, kitérve a politikai elnyomásra, az emberi jogok megsértésére, a jogállamiság és az igazságosság hiányára, a fizikai erőszakra, az emberkereskedelemre, az etnikumok közötti feszültségekre és a terrorizmusra is.

KULCSSZAVAK: Irak, iraki háború, humán biztonság, kisebbségek

\section{Introduction}

The History of insurgency and minority issues in Iraq precedes the 2003 invasion. The Arabization of the minorities affected their status, which was evident in different events and cases. Iraq is mainly composed of three main communities: the Sunni, the Shia and the Kurds

\footnotetext{
${ }^{1} \mathrm{PhD}$ Candidate at the National University of Public Service Budapest, Hungary. Address: 2 Ludovika tér, Budapest, H-1083. Nemzeti Közszolgálati Egyetem doktorandusz hallgató; e-mail: luna.shamieh@gmail.com; https://orcid.org/0000-0002-0401-6881

2 Assistant professor at the International Security Policy Department, National University of Public Service Nemzeti Közszolgálati Egyetem Hadtudományi és Honvédtisztképzö Kar, Nemzetközi Biztonsági Tanulmányok Tanszék; e-mail: molnar.dora@uni-nke.hu; https://orcid.org/0000-0002-1476-5253
} 
(who are mostly Sunni). However, the Mosaic that forms the country is even more complex as it is composed of many ethnic, religious, and ethno-religious minorities.

The Iraqi government accommodated the Kurds during the Iraq-Iran war; a strategy they used to persuade the Kurds not to support Tehran. Nevertheless, the two Kurdish rivals, the Kurdish Democratic Party (KDP) and the Patriotic Union of Kurdistan (PUK), reacted to this accommodation differently. Despite this, in 1988, the Iraqi forces attacked Kurdish targets, including the Halabja incident where 5000 were killed. ${ }^{3}$ Additionally, in 1988, the Iraqi government launched its 'Anfal campaign' against the Kurds forcing Kurds to leave their houses, thus setting up a "cordon sanitaire" along the borders with Iran. Yet, after the 1991 Gulf war, the displaced Kurdish people were able to return to their villages in that zone. ${ }^{4}$

The 1991 Gulf war was followed by uprisings in the south by the Shia and in the north by the Kurds. This was when Kurdish Guerillas "occupied nearly all of the areas they considered historically Kurdish including Kirkuk. Some vengeance killings took place as the population acted out its anger against those associated with the Iraqi government, ... the government soon mounted a counter-offensive and quickly crushed the uprisings". 5 This was when the "no-fly zone" was declared over northern Iraq. In October 1991, the Iraqi government withdrew from Erbil, Duhok and Sulaymaniyah granting de facto autonomy for the Kurds. This guaranteed the return of Kurds to the area while it led to the expulsion of Arabs living in the area. Consequently, the Iraqi government focused on the Arabization of Kirkuk. "Kurds, Turkomans, and Assyrians came under constant pressure to sign "ethnic identity correction" forms relinquishing their ethnicity and registering officially as Arabs". 6

March 2003 marked the turning point in Iraq's history. This was when the invasion started; the invasion was a US call. In November 2002, at the NATO summit, President George W. Bush announced the decision to assemble a "coalition of the willing". In March 2003, the initial list of countries with forty-nine states was announced; by the end of the year the list was reduced to forty-eight after Costa Rica left the coalition. Even though this number was announced differently by dissimilar resources, only four nations sent troops during the invasion, namely the United States, the United Kingdom, Australia and Poland. ${ }^{7}$

\footnotetext{
${ }^{3}$ Katzman 2010, 1.

${ }^{4}$ HRW, 2004: 13.

${ }^{5}$ HRW, 2004: 13-14.

${ }^{6}$ HRW, 2004: 15.

${ }^{7}$ Carney 2011, 1.
} 


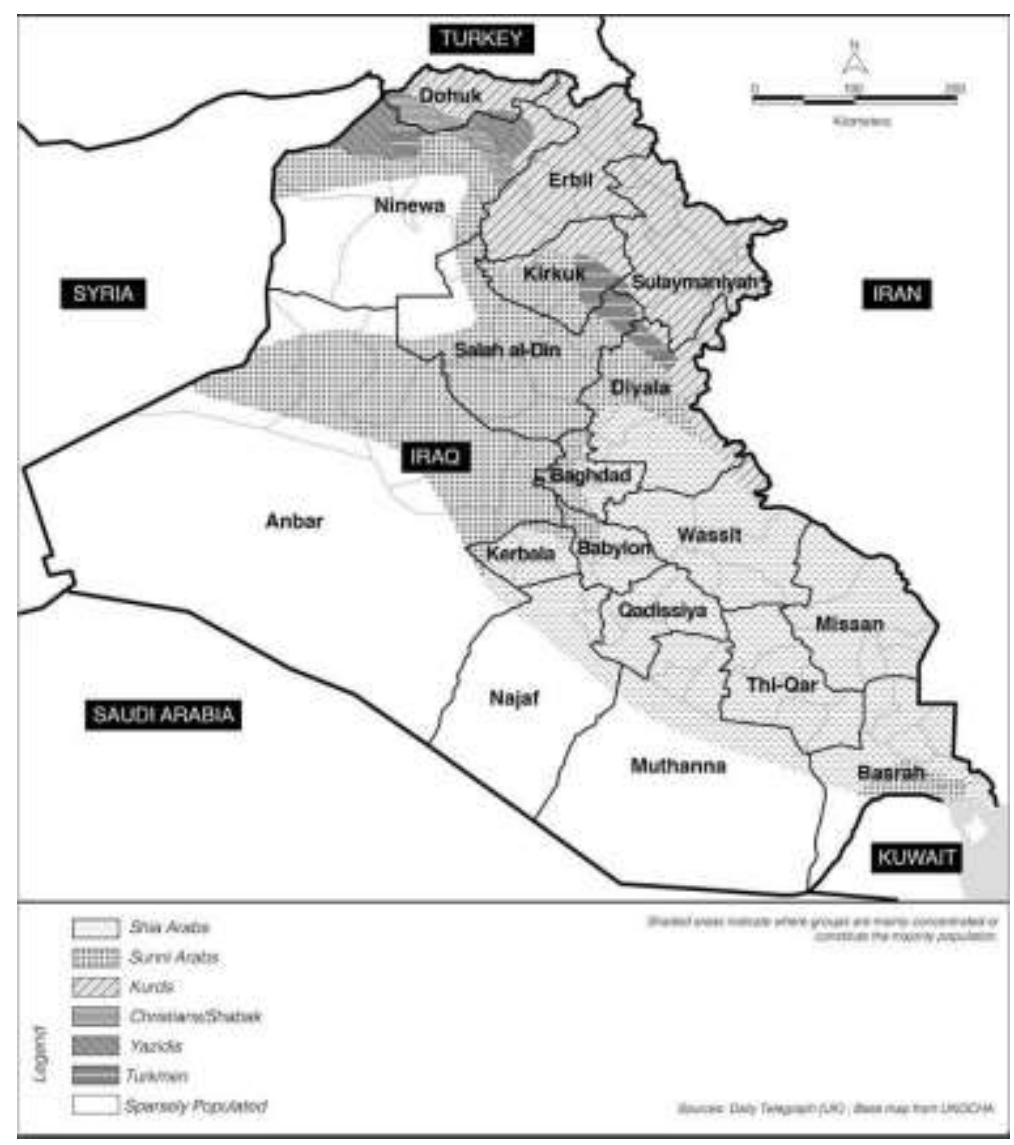

Figure 1.

Map of Iraq showing the Ethno-Religious Population Distribution Before 2014

(Daily Telegraph, base map from UNOCHA)

When the US removed Saddam Hussein from power aiming at replacing the regime, the region shifted to a protracted sectarian violence in a collapsed state. It produced security and organization vacuum; the security forces were not in place anymore and the level of crime increased. Violence against the American forces started in the conservative religious city of Falluja. The attacks against the US forces and the counter attacks gradually increased in the city and spread throughout the country.

On April 16, 2003, General Tommy Franks, the commander of U.S. Central Command, issued a "Freedom Message to the Iraqi People," in which he noted that "I am creating the Coalition Provisional Authority [CPA] to exercise powers of government temporarily." 8 President Bush said that the CPA would establish "an orderly country in Iraq that is free and at peace, where the average citizen has a chance to achieve his or her dreams". 9 To develop the constitution of the new country, the US announced the formation of a constitutional council; however, this was rejected by the Iraqis. This formed two rivals: the Americans with those working for them or part of the new administration structure on the one side and those opposing the Americans on the other. The conflict became even more complex with the different sects being part of the conflict and with the rising of the different insurgencies

${ }^{8}$ Dobbins et. al. 2009, 11.

${ }^{9}$ Dobbins et. al. 2009, 11. 
leading to a low intensity war. The invasion of Iraq was initially a conventional war but developed into a counterinsurgency campaign. ${ }^{10}$

After the 2003 war, there was a change in the sectarian relations in Iraq. With the Shi'a triumph, Sunnis had to familiarize themselves with the new "minority status" "[T] "[Te roles have been reversed: Sunnis have replaced their Shi'i compatriots as the self-perceived victims of sectarian discrimination. It goes without saying that the previous regime was not a "Sunni regime" any more than today's is a Shi'i regime". ${ }^{12}$ The flipped status was attempted through the compensation of the victims (the Kurds and the Shiites) and the punishment of the transgressors (the Sunnis); where the victims were competing to take lead. The first expansion of violence beyond the conflict between the two rivals was in August 2003. It was a car bomb destroying the Jordanian Embassy in Baghdad killing 19 people. After two weeks another explosion targeted the UN headquarters, killing Sergio Viera de Mello, the UN SecretaryGeneral's Special Representative, and 19 others. ${ }^{13}$

Kirkuk witnessed the most severe inter-ethnic tensions between Kurds, Turkomans, and Arabs. Violence erupted between Arabs and Kurds and deadly violence exploded between Turkomans and Kurds. Kurds fought to achieve federalism, while the Turkomans and the Arabs were against this. ${ }^{14}$

Since 2003 Iraq has become a battlefield for al-Qaeda. The marginalization of the Sunni community led to even more conflicts and the resurgence of al-Qaeda. Bombing Sunni resistance led to a high number of displaced and to a higher level of extremism, which created a humanitarian crisis that ended up in targeting the Shia leading to a chaotic situation. In 2004, Abu Musab al-Zarqawi, the leader of al-Qaeda in Iraq started to implement his strategic priorities on the ground, expanding the region beyond Iraq and engaging in mass killings even of other Muslims. By the year 2007, the Iraqi people started considering this movement as terrorism. This is the moment when the al-Qaeda lost the hearts and the minds of the people. This extremism pushed more Iraqis to support the 'Sahwa' (Awakening). ${ }^{15}$

Al-Anbar tribe started its uprising against the al-Qaeda in Iraq in September 2006; which was referred to as Sahwa al-Anbar. This was due to the aggressive measures used by alQaeda. However, it is also related to the fact that al-Qaeda opposed any tribal structure that might affect the alliance with al-Qaeda. ${ }^{16}$ The disloyalty that al-Qaeda saw from the Sunni communities and the Sunni's will for political participation led to massive executions. On the other hand, these measures raised awareness amongst the tribes questioning whether this was truly Islam and that tribal affiliation was a key social safety. ${ }^{17}$

\footnotetext{
${ }^{10}$ Carney 2011, 1.

${ }^{11}$ Haddad 2014, 69.

${ }^{12}$ Haddad 2014, 82.

${ }^{13}$ Metz 2007, 1.

${ }^{14}$ HRW, 2004, 1.

${ }^{15}$ Ross, Gartenstein-Ross \& Jensen 2015, 1.

${ }^{16}$ Ross, Gartenstein-Ross \& Jensen 2015, 102.

${ }^{17}$ Ross, Gartenstein-Ross \& Jensen 2015, 102.
} 


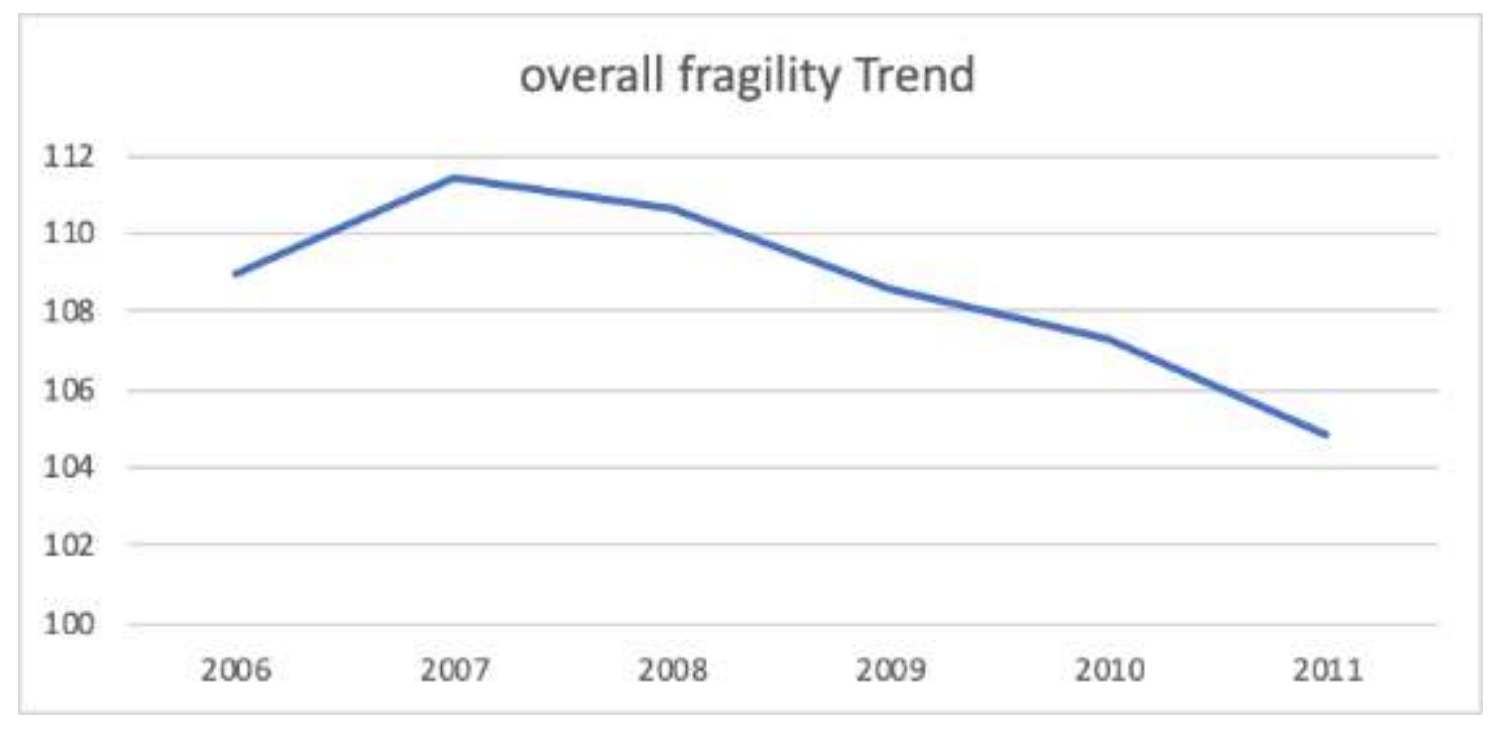

Figure 2.

Overall Fragility Trend (2006-2011)

(Fund for Peace 2019. https://fragilestatesindex.org/country-data/)

The first permanent government was formed by Nouri al-Malki in May 2006, as successor of the Iraqi transitional government that replaced the Iraqi Interim Government in May 2005. From 2006 to 2008 the State Fragility Index ${ }^{18}$ showed extremely high alert where the rank ranged between two and five. During the period from 2009 to 2011 the index ranged from 6 to $9 .{ }^{19}$ Figure (2) below illustrates the State Fragility Index in Iraq in the period between 2006 and $2011 .^{20}$ The graph includes some improvements, though it is still within the high alert category.

\section{Different categories... different interests... segregation}

"As the state collapsed, the illusory veneer of relative uniformity and harmony that the Ba'ath had forcefully and violently upheld was abruptly removed, unleashing passions and identities that had been at best, poorly understood, and at worst, completely overlooked."21

The focus of communal groups in Iraq is mainly on Shiites, Sunnis, and Kurds. However, beyond this the other distinction exists between diverse ethnic, religious, sectarian, and linguistic groups. These minorities have faced intimidation and persecution resulting from this diversity and due to stereotyping of the majority. Some minorities have a distinct ethnic background; others have a different religion or sect, while others have unique ethno-religious background. Those diverse backgrounds embraced cultural distinction with different customs, traditions, clothing, and language.

\footnotetext{
${ }^{18}$ In State Fragility Index country ranking is according to the following: from 1-5 it refer to those with very high alert, ranking from 6-9 refers to those with high alert, 10-31 alert, 32-60 high warning, 61-95 elevated warning, 96-119 warning, 120-132 stable, 133-149 more stable, 150-160 very stable, 161-171 sustainable, 172-178 very sustainable.

${ }^{19}$ Fund for Peace 2019.

${ }^{20}$ No data available prior to 2006.

${ }^{21}$ Haddad 2014, 68.
} 
Discrimination against minorities already existed prior to 2003 and also during the different phases of the insurgency. Discrimination was evident in their daily life events. In some cases, discrimination was also reflected in the law. For example, Law No. 105 of 1970 prohibits the practice of the Baha'i faith, and a 2001 resolution prohibits the practice of the Wahhabi branch of Islam. ${ }^{22}$ The absence of recognition of some religious minorities in Iraq, such as Baha'is, Kaka'is, and Zoroastrians is still a systematic official denial. ${ }^{23}$

\section{Insurgency}

There is a wide range of insurgencies in Iraq that started after 2003, which have passed through different phases. The first phase of insurgencies lasted from 2003 to 2011 following the invasion of Iraq. This refers to the period following the end of Saddam Hussein's regime, where insurgency was mainly against the US-led multinational force along with inter-ethnic tensions. The other phase started after the US withdrawal in 2011, however, a resurgence of the different groups spurred up in 2013.

Different groups with different ideologies and different levels of extremism have emerged, grown and affected the whole region. Some are fighting to change the government while others are striving to affect the people themselves, in many cases affecting the minorities, as well as facing the majority. Some have operated in coalitions, while others clashed with the other insurgents. Some are supporting the return of the Iraqi security forces to the Sunni sect, while others oppose it.

The year 2006 marked the turning point of insurgency in Iraq. This is the so called "AlSahwa" translated as Awakening. The Sahwa movement refers to the change in the Sunni insurgency position, when they took up arms against al-Qaida in Iraq. ${ }^{24}$ In 2011, the ground forces withdrew from Iraq, at the same time when the Prime Minister Nouri al-Malki failed to integrate the Sunni. It led to the exclusion policy started by arresting the bodyguards of the Sunni Finance Minister. Since then, violence started with Sunni calls to support the armed resistance. This initiated tribal militias and insurgent groups (such as the Ba'athist Jaysh Rijal al-Tariq al-Naqshabandia - JRTN). ${ }^{25}$ Figure (3) below illustrates the different insurgent groups which were active during the period 2003-2018, according to Stanford University. About eleven groups started their activities in 2003, six started in 2006/2007, and four in 2013/2014. The following is a list of some insurgency groups active in Iraq during the period 2013-2019. The list shows the complexity in understanding the allies and rivals within the insurgency groups. It shows the different affiliations and the controversial support provided to both insurgents and counterinsurgents.

\footnotetext{
${ }^{22}$ UNHCR, 2018.

${ }^{23}$ Salloum 2016.

${ }^{24}$ Adnan \& Reese 2014, 1.

${ }^{25}$ Adnan \& Reese 2014, 1.
} 


\section{The Islamic State (IS)}

The Islamic State (IS) is also known as the Islamic State of Iraq and Syria (ISIS) and the Islamic State in Iraq and the Levant (ISIL). It is an Islamic Salafist organization that was established with the vision of transnational Islamic State. The IS traces its origin to early 2000 when Abu Musab al-Zarqawi from Jordan became a militia and started Jama'at al-Tawhid wal-Jihad in the Kurdish area of Sulaymaniya targeted by the US troops during the 2003 US invasion of Iraq. This group had three major targets: the Shia, the international community, and Jordan; and hence their terrorist activities were conducted as such. In September 2004, Zarqawi announced the allegiance with al-Qaeda, where the group was then called al-Qaeda in Iraq. The relationship between al-Qaeda in Iraq and al-Qaeda was tense due to different visions and strategies. However, the group remained attractive for supporters and followers. Ideologically, all followers come from the Saudi Wahhabism, those who believed that the Shia were heretics. Zarqawi died in June 2006, and al-Qaeda in Iraq appointed Abu Ayyub alMasri as the new leader. Four months later, the Islamic State in Iraq (ISI) was created. ${ }^{26}$ The group faced a decline after 2011, but later it gained back its strength when it got involved in the Syrian Civil war. Its name was changed to ISIS at that time.

${ }^{26}$ Shamieh \& Szenes 2015, 363. 


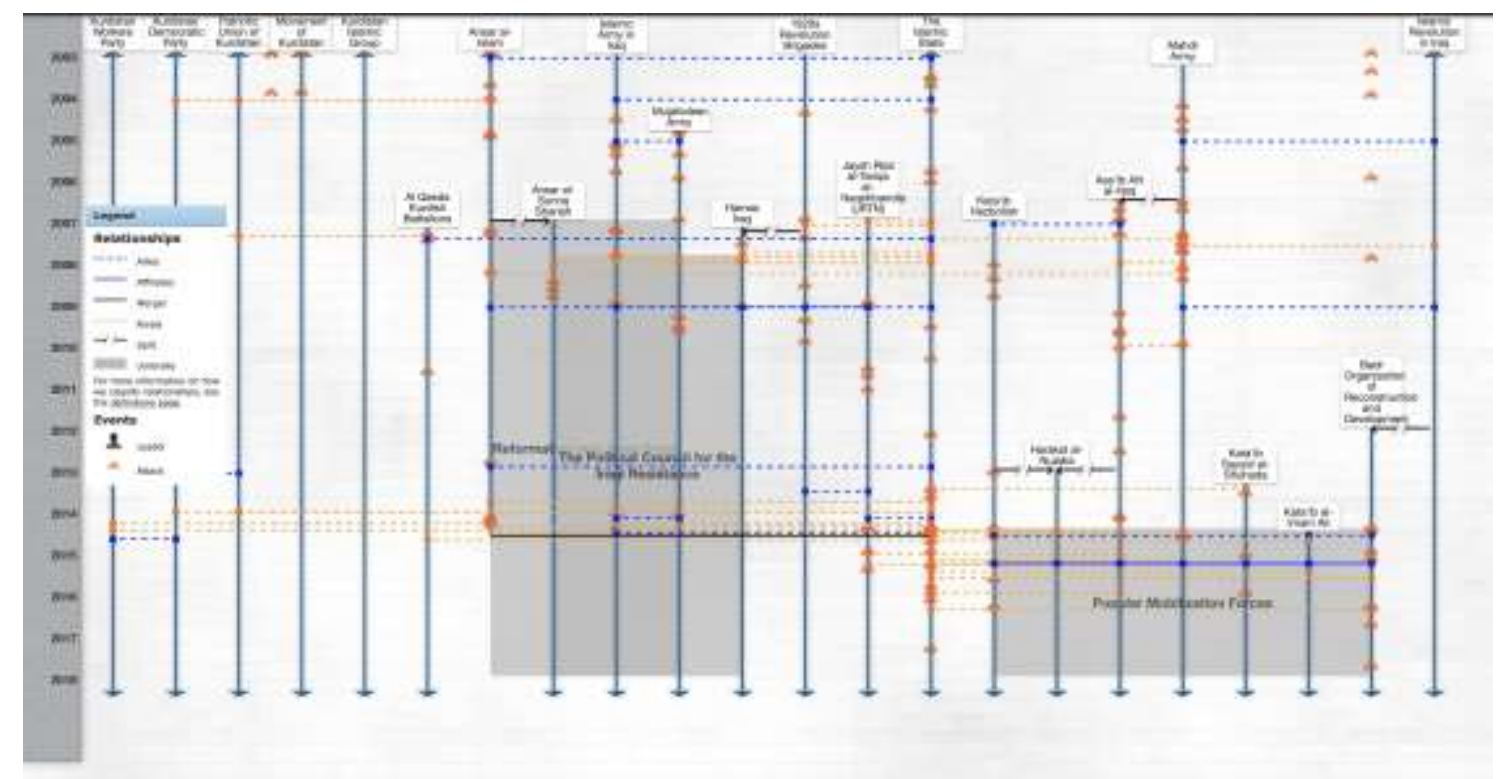

Figure 3.

Map of the Insurgents in Iraq (2003-2018)

(Source: Stanford University [2019] available at: http://web.stanford.edu/group/mappingmilitants/cgibin/maps/view/iraq)

ISIS used intensive attacks targeting civilians - including Shia, Kurds and especially against minorities - who did not accept their vision. ISIS also targeted the Iraqi Security Forces and the international forces. On the ground ISIS fought against the Iraqi security forces, Iraqi militias, the Kurdish peshmerga, the Syrian government forces, the Syrian rebel groups, and the international forces.

Supporters of ISIS ranged from individuals to countries, though there is no clear evidence of any country support. Some claims refer to the Turkish support to ISIS. Support included: facilitation of the passage of foreign jihadists and their families across the Turkish border into the areas controlled by ISIS in Syria and Iraq, the treatment of ISIS wounded in Turkish hospitals, overlooking ISIS activities in Turkey, attacking the Self-Administration in Rojava - North and East Syria, and carrying out massacres against the Kurds. ${ }^{27}$ Many of ISIS members arrived from different nationalities, including Arabs and non-Arabs, Asians, and Europeans. This was accomplished through the marketing strategies ISIS used to recruit new members; locals and internationals. ${ }^{28}$

\section{The General Military Council of Iraqi Revolutionaries}

The General Military Council of Iraqi Revolutionaries (GMCIR) is a Ba'athist militant group. An estimated 75,000 fighters are affiliated to GMCIR, mostly concentrated in Anbar, SalahalDin and Ninewah governorates. ${ }^{29}$ Reports also claim that the GMCIR is affiliated to the Jaysh Rajaal al-Tariqa al-Naqshabandia (JRTN - Army of the Men of the Naqshabandi Path). The

\footnotetext{
${ }^{27}$ NRLS, 2019.

${ }^{28}$ Shamieh \& Szenes 2015, 363.

${ }^{29}$ Heras 2014, 4.
} 
relationship between this group and ISIS is also controversial, as they admit their participation in ISIS operations. ${ }^{30}$ However, GMCIR do share the same ideological orientation of ISIS. ISIS fights were mainly against non-Sunni religious and ethnic communities; whereas GMCIR is mainly a nationalist movement seeking Iraqi unity despite the controversial operations in which they were included. ${ }^{31}$

GMCIR seeks substantial changes in the socio-political system and are anti-Maliki and anti-Iranian. The challenges this insurgency faces include the rejection of the Shia, the association with ISIS, as well as its association with tribal militias. ${ }^{32}$

\section{Jaysh Rajaal al-Tariqa al-Naqshabandia (JRTN)}

JRTN is considered to constitute the second largest insurgent group after ISIS. It was formed by Saddam Hussein's right-hand man, Izzat Ibrahim al-Douri in 2006 as the main front for Baathist insurgents. This group is an amalgamation of the secular nationalism and the Naqshbandi Sunni Islam; however, it utilizes the jihad terminology to gain religious legitimacy. Despite its distinct ideology, JRTN worked closely with ISIS especially in 2014 during the capturing of Mosul. ${ }^{33}$

\section{The Fallujah Military Council}

The Falluja Military Council was created to face ISIS operations in Falluja. On July 8 2014, ISIS reportedly executed a number of Fallujah gunmen for refusing to pledge allegiance to ISIS leader Abu Bakr al- Baghdadi. ${ }^{34}$

\section{Brigades}

The 1920 Brigades group name refers to the 1920 revolution against the British colonial rule in Iraq. The group was established in 2003 to free Iraq from foreign occupation particularly from "American military and political presence". ${ }^{35}$ That is why the majority of the attacks were against the US soldiers and bases. In 2007 and after Al-Qaeda's assassination of several group's members; the 1920 Brigades were divided amongst themselves, opposing Al-Qaeda and cooperating with the US or vice versa. Those who decided to cooperate with Al-Qaeda and oppose the US formed a new group called Hamas Iraq. The assassinations, the divisions amongst the group and the internal conflict led to the weakening the group. As of 2019, there is limited presence of the group with no publications or political activity. ${ }^{36}$

\footnotetext{
${ }^{30}$ Adnan \& Reese 2014, 1.

${ }^{31}$ Adnan \& Reese 2014, 1.

${ }^{32}$ Heras 2014, 4.

${ }^{33}$ CISAC, 2019a.

34 Adnan \& Reese 2014.

${ }^{35}$ CISAC, 2019a.

${ }^{36}$ CISAC, 2019b.
} 


\section{The Islamic Army in Iraq}

The Islamic Army group in Iraq (IAI) was formed in 2003 following the 2003 invasion of Iraq by the United States and coalition military forces. From 2003-2011, the group targeted the US military forces, while in 2006 several clashes were reported against Al-Qaeda. The group's operations declined in 2008 and rose again in 2014. The IAI's vision is to participate in a political solution for Iraq. ${ }^{37}$

\section{Counterinsurgency}

Following 2003, the coalition forces removed all the traces of the previous regime; which led to a high level of unemployment, lack of food security, lack of economic security, and lack of national security. ${ }^{38}$

Different nationalities participated in the Coalition and the counterinsurgency battles. A significant number of troops were composed of US troops included half of the ground forces and the other half formed by the other nationalities (see figure 4 below). ${ }^{39}$ During the invasion phase the belligerents included the United States, the United Kingdom, Australia, Poland, and the Peshmerga forces supported by Canada, Netherlands and Italy from one side and the Iraqi government from the other side. During the post invasion phase (2003-2011), the belligerents included the United States, the United Kingdom, the Coalition Forces, the new Iraqi government supported by Iran, Iraqi Kurdistan the Baath loyalist, Sunni insurgents, and Shia insurgents.

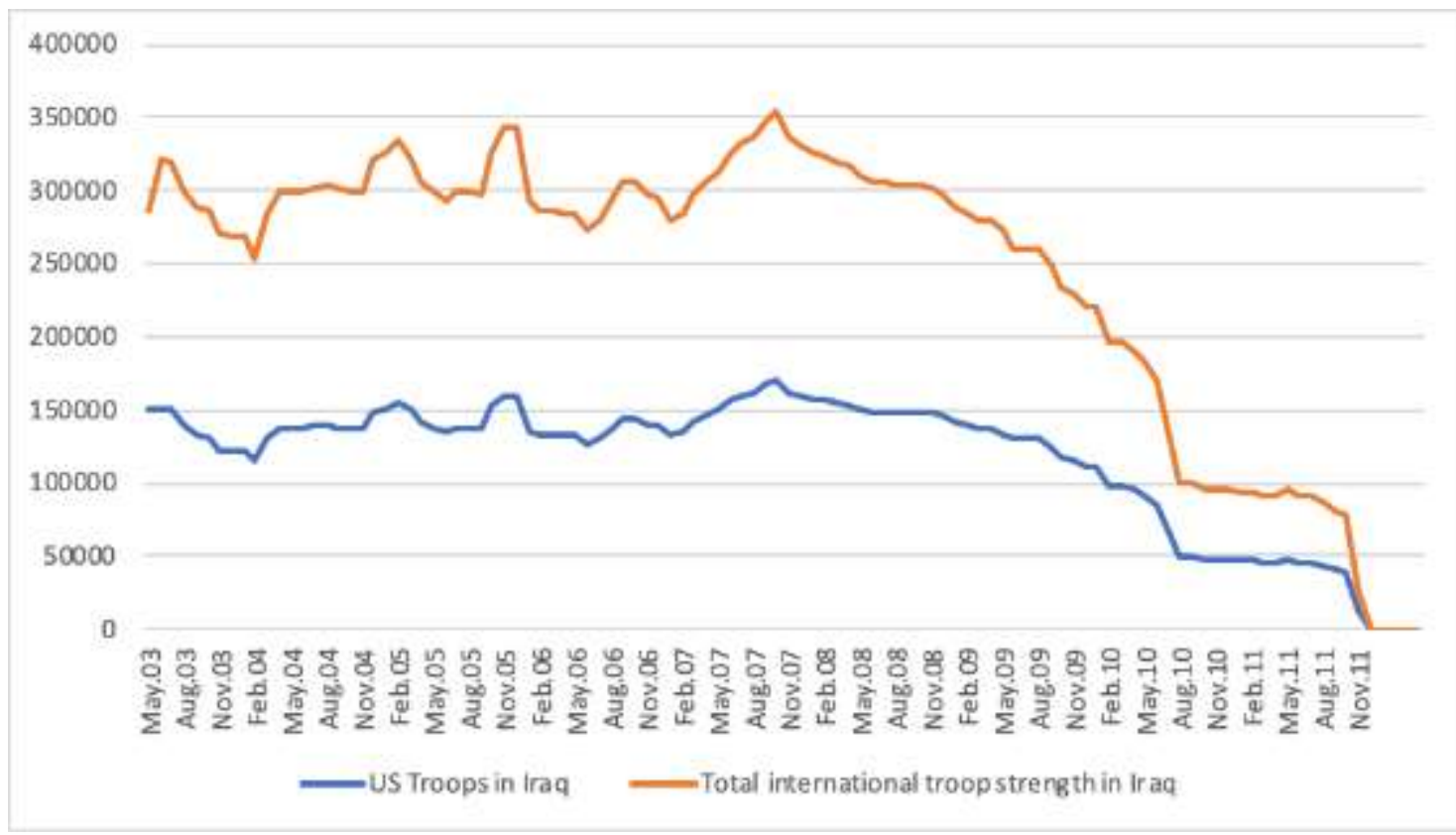

Figure 4.

International Troops in Iraq (2003-2011)

(Raw data available in Brookings Report "Iraq Index")

\footnotetext{
${ }^{37}$ Adnan \& Reese 2014, 19.

${ }^{38}$ Mabon \& Royle 2017, 1.

${ }^{39}$ O'Hanlon \& Livingston 2013, 1.
} 
Different other players of the conflict were active, but in some cases, it was not even clear whether they were supporting the insurgents or the counterinsurgents. The ups and downs in the American-Turkish relations were also evident in the variations of support. ${ }^{40}$

Private security contractors were also employed to provide services in Iraq. Services included: protecting fixed locations, guarding traveling convoys, providing security escorts, and training military personnel. The peak was in 2009 with employing more than 15,000

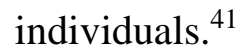

Counterinsurgency experienced in Iraq ranged from absolute failure as assessed by the different belligerents to some success. The 'Operation Vigilant Resolve' that started in April 2004 in response to the killing of four American contractors in the city was an example of the information operation (IO) failure. It was the first Marine assault on Falluja, where two marine battalions began their attack on insurgent positions. This battle confronted 300,000 citizens along with 2,000 insurgents. The battle was considered unsuccessful, and a turning point in US counterinsurgency strategy:

"Two reinforced battalions were tasked with isolating and attacking a medium-sized city . . . Depending on the tactical situation, manpower shortages may be compensated for by increased firepower, which the Marine commanders were unwilling-or unable-to apply in Valiant Resolve. Indeed, it appears that leaders at the scene quickly came to this conclusion. The operation never progressed beyond the foothold stage. Marines gained access to the urban area (in that case, outlying industrial neighborhoods), but did not penetrate to the heart of the city, much less take it." 42

Reports referred that the marines did not expect the high level of preparedness of the insurgents, which caused heavy losses. It was definitely a huge loss in the information operations. The insurgents themselves considered it a great victory, where the city became totally controlled by the insurgents and the supporting foreign fighters. ${ }^{43}$

Other operations were successful. Following the Fallujah failure, Muqtada al Sadr's antigovernment Mahdi militia attacked government forces in the city. Within three weeks the Sadr's militia was defeated. This opened eyes back again to Fallujah. ${ }^{44}$

In 2008, to achieve the long-term security plan, the US paid salaries through the Iraqi Prime Minister Nouri al-Malki to the fighters, so that this could be the future responsibility of the ministry of defense, while providing support to the reconstruction fund. Due to the lack of transparency (as nobody knew where this money went), the situation became increasingly chaotic. $^{45}$

"In essence, Sunni Arabs tribes became part of the Sunni 'problem', struggling for power and resources, and divided over how to respond to the worsening political-economic conditions. Al-Maliki was able to use these schisms for his own benefit, playing Sunni groups and tribes against one another across his tenure. As Sunni Arab tribal politics interacted with

\footnotetext{
${ }^{40}$ Dağci 2012, 1.

${ }^{41}$ CRS, 2019.

${ }^{42}$ Matthews 2010, 9.

${ }^{43}$ Matthews 2010.

${ }^{44}$ Matthews 2010.

${ }^{45}$ Mabon \& Royle 2017.
} 
politics at the national level, the identity of the tribal movement that had been briefly established during the Sahwa eroded, and the tribes once again became fragmented. "46

Iraq's neighboring countries were also part of the game. Kuwait for example had concerns of the Iranian influence and of the spillover of Iraqi Shia across its own borders; therefore, Kuwait provided support to the US military action. Qatar also supported the US military by hosting the central command; though it also hosted the former Iraqi Baathists. ${ }^{47}$ Iran also supported the Iraqi Shiite insurgency by "material support". 48

Sectarian violence has escalated since counterinsurgency started, different parties have been engaged in the conflict and the complexity and intensity of the conflict have increased by time. Counterinsurgency operations were activated and support to the different parties were provided either internally or externally and either physically or financially. Different lines of communications were initiated either as rivals or supporters.

\section{Impact of Counterinsurgency}

The counterinsurgency has led indirectly to an escalation of refugee influx along with the deterioration in human security. This section illustrates the factors affected.

Although displacement was ongoing, there were two exact peeks; the first in 2006 when the Sunni-Shia violence forced thousands of minority families, the second in 2008 when violence against Christians, Yezidis forced thousands of families to flee their homes. ${ }^{49}$ 25-30 percent of the population have been forced to leave their homes and are either internally or externally displaced. ${ }^{50}$ More than 80 percent of the Mandaean population were forced to leave; 60 percent of Christians and other ethnic or religious groups are displaced. Most of the Yezidi and Kaka'i were forced from Ninewa and subsisting as IDPs. ${ }^{51}$ Table (1) below shows the number of IDPs throughout the period. Despite the significant number of returnees, that displacement has yet to be over until the current period.

Table 1.

IDPs in Iraq (2003-2011)

(Source: Brookings Report “Iraq Index”)

\begin{tabular}{|c|c|}
\hline Year & Internally displaced \\
\hline 2003 & 400,000 \\
\hline 2004 & 800,000 \\
\hline 2005 & $1,200,000$ \\
\hline 2006 & $2,000,000$ \\
\hline 2007 & $2,740,000$ \\
\hline 2008 & $2,770,000$ \\
\hline 2009 & $2,764,000$ \\
\hline 2010 & $2,700,000$ \\
\hline
\end{tabular}

\footnotetext{
${ }^{46}$ Mabon \& Royle, 2017, 91.

${ }^{47}$ Alterman, 2007. 1.

${ }^{48}$ CFR, 2008.

${ }^{49}$ Lamani, 2009.

${ }^{50}$ Lamani, 2009.

${ }^{51}$ IILHR, 2016.
} 
The following section involves a quick summary of the three most relevant human insecurity dimensions: that of community, political, and personal.

\section{Community Security}

Iraqis are facing the breakdown of their families and communities because of the conflict, collapse of cultures; people are desperate that the community will get back to the pre-2003 era. The Iraqis interviewed revealed that the suffering during Saddam regime was not as harmful as the suffering they are facing now as individuals, communities and as a nation. They noted the inter-ethnic and identity-based tensions pre-2003, but they declared that the situation has deteriorated since there is no potential of advancing back to that point.

"At his most vulnerable position, Saddam Hussein used sectarianism and nationalism as weapons against his internal enemies," the Civil-Military Fusion Centre (CFC) wrote in a recent briefing on the risk of a renewed breakout of large-scale violence. "Today's Iraqi Shiite parties and government appear to be doing far worse as governmental rule is justified on a sectarian basis. " 52

The rise in terrorism was evident through the escalating number of terrorist attacks (see figure 5 below). Again, the attacks may have decreased later; however, this has not approached the pre-2003 era. Moreover, it is clearly evident through the "unprecedented education, testing their [Al Qaeda] mettle against the best trained military in the world'. ${ }^{53}$

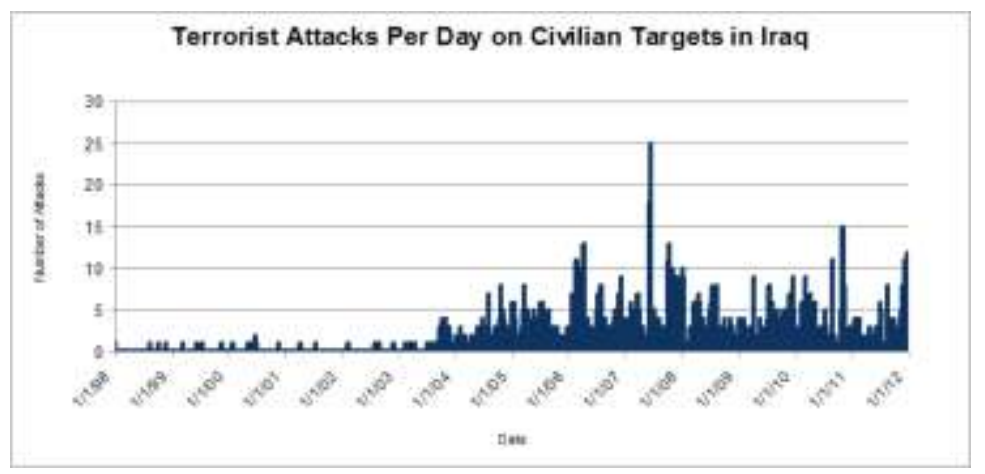

Figure 5.

Terrorists Attacks per Day on Civilian Targets in Iraq

(Source: Stern \& McBride, 2013)

Number of deaths resulting from terrorist attacks has also increased, figure (6) below shows the number of deaths resulting from terrorism. The number has been on the rise since the 2003 invasion. Tensions including ethnic and religious tensions have affected all factions of the society.

\footnotetext{
${ }^{52}$ IRIN, 2013.

${ }^{53}$ Stern \& Mcbride, 2013, 2.
} 


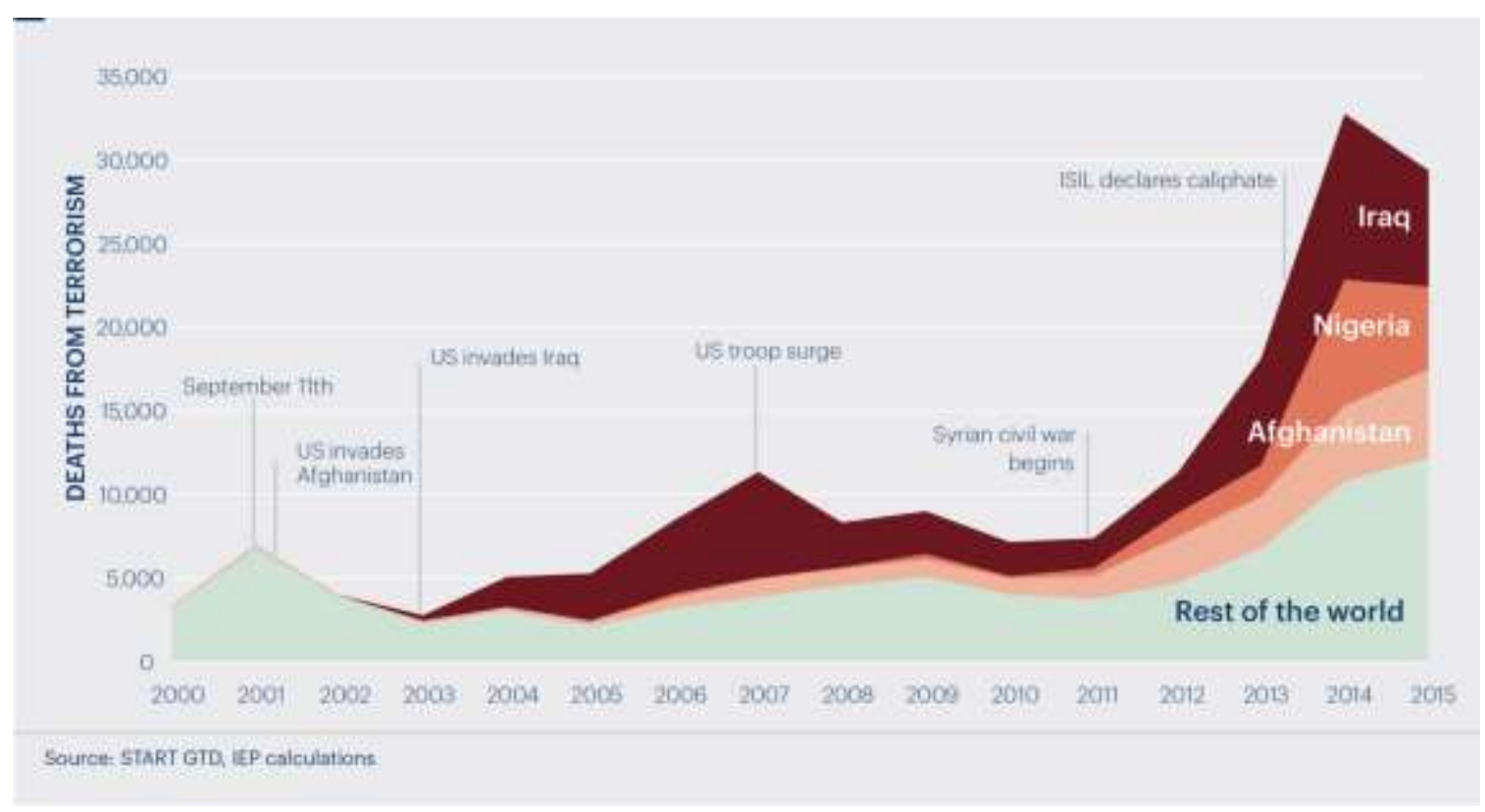

Figure 6.

Deaths from Terrorism, 2000-2015

(Source: IEP, 2016:16)

According to UNHCR statistics, about 700,000 Iraqis took refuge in Syria between October 2003 and March 2005. In the same period 5,843 cases (15,855 persons) were registered as asylum-seekers by UNHCR in Damascus out of which $36 \%$ were Christians. ${ }^{54}$

\section{Political Security}

Severe human rights violations have been prevalent in Iraq. Violations include war crimes and crimes against humanity, terror attacks and sexual abuse, leaving millions of civilians without home and forced them to flee.

Abuses during detention and imprisonment have been on the rise. Iraq is the world's third country in the number of prisoners. At least 169 prisoners were executed in 2013; this figure has been the highest ever. ${ }^{55}$ According to the Human Rights Watch Report (2010) there is serious delays in the judicial review, some detainees spend years in custody without trial or even charge. Detainees face torturing with no access to families or lawyers. In 2010, Iraq was one of the most dangerous countries to work in the media, with no freedom of expression and no freedom of assembly. ${ }^{56}$

Human rights violation is faced through the government, militias and even the international forces.

"Thousands of classified files were published by Wikileaks. These showed, among other things, that US troops manning security roadblocks had shot dead many Iraqi civilians in previous years and that, contrary to their denials, the US military authorities had sought to keep a count of the number of Iraqi civilians killed in the conflict in Iraq. Revised estimates

\footnotetext{
${ }^{54}$ UNHCR, 2005.

${ }^{55}$ Amnesty, 2014.

${ }^{56} \mathrm{HRW}, 2010$.
} 
put the total number of civilian casualties in the conflict in Iraq between 2004 and 2009 at 66,081." 57

Corruption has also increased since 2003. According to Transparency International the corruption index reached 1.8 ranked Iraq as $175^{\text {th }}$ country in 2011 , whereas it was ranked $113^{\text {th }}$ in 2003 by its point 2.2 .

\section{Personal Security}

Iraq was well known as one of the richest countries, with high level of literacy and a high number of professionals and university graduate. However, this is no longer a matter of comparison. A huge number of those immigrated, while the remaining is working under strain and threats. ${ }^{58}$

Level of violence expanded to reach all the different regions and the different communities in Iraq. Minorities were the most affected; where they faced discrimination, violence and ethnic cleansing. Different massacres took place against different communities especially against the Yezidis. Those minorities were not part of the conflict, but they ended to be victims of the war. Gender-Based Violence (GBV) was also evident. In Basra, 133 women were killed by Islamist militias in 2007. Their bodies were dumped in rubbish tips with notes warning others against "violating Islamic teachings". 59

Human trafficking has become a prevalent issue since 2003. Kidnapping especially in Baghdad has increased noticeably. Houses were found that stored girls for selling in other countries. Trafficking of kidnapped females to other countries has been on the rise since then. Statistics in this period are not available as the term human trafficking has yet to be used.

In 2004, a survey conducted by Women International revealed that $90 \%$ of women in Iraq felt that there was a hope for a secured future. However, this percentage declined by $27 \%$ in 2008. ${ }^{60}$ Mass number of women accused of prostitution were killed between 2006 and $2008 .^{61}$

\section{Conclusion}

The war in Iraq led to a complete chaos against all aspects of the society. This has led to the increase in migration and displacement; it also led to the fragmentation that created different centers of mass, meaning various centers of gravity for the different segments of the society. The result is a massive deterioration in human security. The fragmentation and the diverse centers of mass also created a community that is no longer like the original structure. In fact, new communities were multiplied that do not accept or appreciate the differences.

While conflict has declined in the last few years, the level of security has not returned to pre-invasion levels. Number of terrorist attacks, deaths, and violence against the different

\footnotetext{
${ }^{57}$ Amnesty International, 2011.

${ }^{58}$ Ihsanoglu, 2007, 915.

${ }^{59}$ IRIN, 2010: 15.

${ }^{60}$ NCA, 2010.

${ }^{61}$ Khadim \& Khrassn 2016.
} 
minorities are still on the rise. The protracted conflict and the failure to reconstitute the government created a fertile base for terrorists to fight; new groups of insurgents are still being formed until this time.

\section{REFERENCES}

Adnan, Sinan \& Reese, Aaron 2014. Beyond the Islamic State: Iraq's Sunni Insurgency. Middle East Security Report 24. Institute for the Study of War, US. Accessed on November http://www.understandingwar.org/sites/default/files/Sunni\%20Insurgency\%20in\%20Iraq. pdf

Alterman, Jon B. (2007). Iraq and the Gulf States: The Balance of Fear. Special Report 189, United States Institute for Peace. Accessed on November 2, 2019. https://www.usip.org/sites/default/files/sr189.pdf

Amnesty (2014). Iraq Human Rights: Human Rights Concern. Accessed on November 2, 2019. https://www.amnestyusa.org/countries/iraq/

Amnesty International (2011). Amnesty International Annual Report 2011-Iraq. Accessed on November 2, 2019. https://www.refworld.org/docid/4dce1562c.html

Carney, Stephen A. (2011). Allied Participation in Operation: Iraqi Freedom. Center of Military History United States Army, Washington, D.C. Accessed on November 2, 2019. https://history.army.mil/html/books/059/59-3-1/CMH_59-3-1.pdf

CFR 2008. Iran's Involvement in Iraq. Council on Foreign Relations. Accessed on November 2, 2019. https://www.cfr.org/backgrounder/irans-involvement-iraq

CISAC 2019a. Mapping Militant Organizations: Jaysh Rijal al-Tariqa al-Naqshbandia JRTN. Center for International Security and Cooperation, Stanford University. Accessed on November 2, 2019. http://web.stanford.edu/group/mappingmilitants/cgibin/groups/view/75

CISAC 2019b. 1920s Revolution Brigades. Mapping Militant Organizations. Center for International Security and Cooperation, Stanford University. https://cisac.fsi.stanford.edu/mappingmilitants/profiles/1920s-revolution-brigades (accessed on November 2, 2019)

Cook, Joana \& Vale, Gina 2018. From Daesh to Diaspora: Tracing the Women and Minors of Islamic State. International Centre for the Study of Radicalization, Department of War Studies, King's College London. Accessed on November 2, 2019. https://icsr.info/wpcontent/uploads/2018/07/Women-in-ISIS-report_20180719_web.pdf

CRS 2019. Department of Defense Contractor and Troop Levels in Afghanistan and Iraq: 2007-2018. CRS Report R44116 May 10, 2019. Congressional Research Service. Accessed on November 2, 2019. https://fas.org/sgp/crs/natsec/R44116.pdf 
Dağc1, Gül Tuba 2012. Turkey-US Relations in Justice and Development Party's Era. Turkish Journal of International Relations 11 (2), Accessed on November 2, 2019. https://dergipark.org.tr/download/article-file/19287

DFAT 2018. DFAT County Information Report Iraq. Department of Foreign Affairs and Trade, Australian Government. https://dfat.gov.au/aboutus/publications/Documents/country-information-report-iraq.pdf Accessed on November $2,2019$.

Dobbins, James et.al. 2009. Occupying Iraq: A History of the Coalition Provisional Authority. RAND National Security Research Division. Accessed on November 2, 2019. https://www.rand.org/content/dam/rand/pubs/monographs/2009/RAND_MG847.pdf

Fund for Peace 2019. Available at: 2019. https://fragilestatesindex.org/country-data/

Gartenstein-Ross, Daveed \& Jensen, Sterling 2015. "The Role of Iraqi Tribes After the Islamic State's Ascendance.” Military Review 2015 (July-August): 102-110.

Haddad, Fanar 2014. Sectarian Relations and Sunni Identity in Post-Civil War Iraq. Sectarian Politics in the Persian Gulf. Ed. Potter, Lawrence G., New York: Oxford University Press.

Heras, Nicholas A. 2014. "The Tribal Component of Iraq's Sunni Rebellion: The General Military Council for Iraqi Revolutionaries." Terrorism Monitor 12 (13): 4-6.

HRW 2004. "Claims in Conflict: Reversing Ethnic Cleansing in Northern Iraq." Human Rights Watch Reports 16(4E). Accessed on November 2, 2019. https://www.hrw.org/reports/2004/iraq0804/iraq0804.pdf

HRW 2010. World Report 2011: Iraq - Events of 2010. Human Rights Watch Accessed on November 2, 2019. https://www.hrw.org/world-report/2011/country-chapters/iraq

IEP 2016. Global Terrorism Index: Measuring and Understanding the Impact of Terrorism. Institute for Economics and Peace. Accessed on November 2, 2019. http://visionofhumanity.org/app/uploads/2017/02/Global-Terrorism-Index-2016.pdf

Ihsanoglu, Ekmeleddin 2007. "Assessing the Human Tragedy in Iraq." International Review of the Red Cross 89 (868): 915-927.

IILHR 2016. No Way Home: Iraq's Minorities on the Verge of Disappearance. Minority Rights Group International, the Institute for International Law and Human Rights, No Peace Without Justice, the Unrepresented Nations and Peoples Organization and the Ceasefire Centre for Civilian Rights. ISBN: 978-1-907919-81-7. Accessed on November 2019. https://minorityrights.org/wpcontent/uploads/2016/07/MRG_CFRep_Iraq_Aug16_UPD-2.pdf

IRIN 2010. Gender-Based Violence in Iraq: The Effects of Violence - Real and Perceived-on the lives of Women, Girls, Men and Boys in Iraq. Accessed on November 2, 2019. http://lastradainternational.org/lsidocs/824\%20gender\%20violence\%20in\%20Iraq.pdf

IRIN 2013. Iraq 10 years on: Human Security; More freedom but less security?, 29 April 2013, Accessed on November 2, 2019. https://www.refworld.org/docid/517f96f04.html

Jones, Seth G. 2008. Counterinsurgency in Afghanistan. RAND, National Defense Institute. Accessed on November 2, 2019. https://www.rand.org/pubs/monographs/MG595.html 
Katzman, Kenneth 2010. The Kurds in Post-Saddam. Congressional Research Service. Accessed on November 2, 2019. https://fas.org/sgp/crs/mideast/RS22079.pdf

Khadim, Ahmed Adnan \& Khrassn, Basim Ali 2016. Human Trafficking and Sexual Exploitation: Iraq as a Case Study. Democratic Arab Center. Accessed on November 2, 2019. https://democraticac.de/?p=36202\#_ftn11

Lamani, Mokhtar 2009. Minorities in Iraq: The other Victims. The Centre for International Governance Innovation, CIGI. Accessed on November 2, 2019. https://www.cigionline.org/sites/default/files/minorities_in_iraq_final.pdf

Mabon, Simon. \& Royle, Stephen. 2017. The origins of ISIS: the collapse of nations and revolution in the Middle East. London; New York, NY: I.B. Tauris \& Co. Ltd 2017.

Matthews, Matt. M. 2010. Operation Al-Fajr: A Study in Army and Marine Corps Joint Operations. Combat Studies Institute Press, Fort Leavenworth, Kansas. Accessed on November 2, 2019. https://www.armyupress.army.mil/Portals/7/combat-studiesinstitute/csi-books/matthews_fajr.pdf

MAU 2009. Mandaean Human Rights Annual Report. Mandaean Human Rights Group. $\begin{array}{llll}\text { Accessed } & \text { on } & \text { November } & 2019 .\end{array}$ http://www.genocidewatch.org/images/Syria_09_11_xx_Mandaean_human_rights_annu al_report.pdf

Metz, Steven 2007. Learning from Iraq: Counterinsurgency in American Strategy. Accessed on November 2, 2019. https://ssi.armywarcollege.edu/pdffiles/PUB752.pdf

MSF 2013. Healing Iraqis: The Challenges of providing Mental Health Care in Iraq. Médecins Sans Frontieres. Accessed on November 2, 2019. https://www.msf.org/sites/msf.org/files/english_iraq_mental_health_final_report.pdf

Muwafaq, Ahmad 2018. The Shabak minority of Iraq Pays the Price for Political Change. Accessed on November 2, 2019. https://fanack.com/religions/shabak-minority/

NCA 2010. Trafficking, Sexual Exploitation and prostitution of Women and Girls in Iraq. Norwegian Church Aid, Accessed on November 2, 2019. https://www.kirkensnodhjelp.no/contentassets/c1403acd5da84d39a120090004899173/20 10/report-trafficking-in-iraq-pdf.pdf

NRLS 2019. Links Between the Turkish State (AKP) and (ISIS). Rojava Center for Strategic Studies. Accessed on November 2, 2019. https://nrls.net/en/

O'Hanlon, Michael E. \& Livingston, Ian 2013. Iraq Index: Tracking Variables of Reconstruction \& Security in Iraq. The Brookings Institute, Accessed on November 2, 2019. https://www.brookings.edu/wp-content/uploads/2016/07/index20130726.pdf

Rawaf, S. et. al. 2014. "Living Conditions in Iraq: 10 Years After the US-Led Invasion." Journal of the Royal Society of Medicine 107 (5): 187-193.

Salloum, Saad 2016. Violence Against Minorities in Iraq: Factors, Indicators, Key Actors, Capacity-Building, and an Early Warning System. Heartland Alliance International, MCMD. Accessed on November 2, 2019. http://masaratiraq.org/wpcontent/uploads/2016/10/vol-5-E.pdf 
Shamieh, Luna \& Szenes, Zoltan 2015. "The Rise of Islamic State of Iraq and Syria (ISIS)." AARMS 14 (4): 363-378.

Stern, Jessica \& McBride, Megan K. 2013. Terrorism after the 2003 Invasion of Iraq. $\begin{array}{llll}\text { Accessed } & \text { November } & 2019 .\end{array}$ https://watson.brown.edu/costsofwar/files/cow/imce/papers/2013/Terrorism\%20after\%20 the $\% 202003 \% 20$ Invasion\%20of\%20Iraq.pdf

UNHCR 2005. Background Information on the Situation of Non-Muslim Religious Minorities in Iraq. available at: https://www.refworld.org/pdfid/4371cf5b4.pdf

UNHCR 2018. Situation of Christians in Baghdad. Accessed on November 2, 2019. https://www.refworld.org/pdfid/5a66f80e4.pdf

WHO 2011. Country Statistical Profiles. Annual Report of the Regional Director. Accessed $\begin{array}{lll}\text { on } & \text { November } & 2019 .\end{array}$ http://applications.emro.who.int/docs/RD_Annual_Report_2011_country_statistics_EN_ 14587.pdf 